R. WILDAN PRATAMA INDRA KUSUMAH, NANA SUPRIATNA, YANI KUSMARNI

JALAN DAMAI MENUJU KEAMANAN REGIONAL: PENDEKATAN ASEAN DALAM UPAYA

PENYELESAIAN KONFLIK LAUT CHINA SELATAN

\title{
JALAN DAMAI MENUJU KEAMANAN REGIONAL: PENDEKATAN ASEAN DALAM UPAYA PENYELESAIAN KONFLIK LAUT CHINA SELATAN
}

\author{
Oleh: \\ R. Wildan Pratama Indra Kusumah, Nana Supriatna, Yani \\ Kusmarni ${ }^{1}$
}

\begin{abstract}
The research aimed to have an in-depth study about the development of South China Sea issue that involved countries such as China, Vietnam, Philippines, Malaysia Brunei Darussalam and the ASEAN's role as a Regional Organization in that conflict. In general, this study wants to answer the question about "how is ASEAN's approaches in order to reconcile South China Sea Conflict peacefully?". To examine the problem, researcher conducted a study by using historical method that includes four research steps namely collecting of written source through literature study (heuristics), source criticism, interpretation or source analysis and historiography. Researcher also using concepts to simplify the analysis, of which are a regional organization concept, a concept of interest, an international dispute concept, a conflict concept, diplomatic concept, and the law of the sea concept. A rationalisation for this South China Sea study, because the issue remains dynamic and it is difficult to find a solution. Many perspectives regarding claims that were made by countries around the South China Sea and the potentials aspects that embedded could disrupt peace and stability in the region's security. These issues become challenging for ASEAN. The resulting study found that: there are numbers of a mechanism such as an informal, semi-formal and formal mechanism. However, those mechanisms have not been able to resolve the conflict. Several efforts have been made to prevent military conflicts. In its development, the South China conflict has shown a more positive progress.
\end{abstract}

Keywords: ASEAN, Claimant States, South China Sea.

\section{PENDAHULUAN}

Laut China Selatan merupakan "laut setengah tertutup" (semi-enclosed sea). Letaknya yang dikelilingi oleh berbagai negara karena merupakan laut setengah tertutup berakibat pada kesulitan penentuan batas wilayah laut dari masing-masing negara, sehingga hal tersebut menjadi salah satu faktor yang menyebabkan wilayah Laut China Selatan tersebut menjadi sengketa beberapa negara yang kemudian berujung kepada konflik. Menurut Nainggolan (2013, hlm. 7), sengketa kepemilikan atau kedaulatan teritorial di Laut China Selatan

\footnotetext{
${ }^{1}$ R. Wildan Pratama Indra Kusumah adalah mahasiswa pada Departemen Pendidikan Sejarah FPIPS UPI, Nana Supriatna dan Yani Kusmarni adalah dosen pembimbing I. Penulis dapat dihubungi di email : rwildanpik@gmail.com.
} 
sesungguhnya merujuk pada kawasan laut dan daratan di dua gugusan kepulauanyaitu Paracel dan Spratly. Kepulauan Paracel dan Spratly kemungkinan memiliki cadangan besar sumber daya alam di sekelilingnya. China memperkirakan cadangan minyak yang terkandung sebanyak 213 miliar barel atau sepuluh kali lipat dari cadangan milik Amerika Serikat (Wiranto, 2016, hlm. 42). Sumber daya alam yang terdapat di Laut China Selatan bukan hanya sebatas minyak bumi dan bahan mineral lainnya saja, sumber daya laut yang dihasilkan juga sangat melimpah, laut ini terkenal dengan berbagai macam jenis ikan. Selain itu, daya tarik Laut China Selatan tersebut juga terdapat pada fungsinya sebagai jalur perdagangan. Hal tersebut yang membuat negara-negara maju menjadikan stabilitas kawasan Laut China Selatan sebagai prioritas dalam aktivitas politik luar negerinya.

Akar dari konflik Laut China Selatan dimulai ketika klaim pertama kali pada tahun 1947 oleh China yang secara sepihak mengklaim hampir seluruh wilayah Laut China Selatan dengan menerbitkan peta yang memberi tanda sembilan garis putusputus di seputar wilayah itu (Akmal \& Pazli, 2016, hlm. 2). Dalam perkembangannya, klaim tersebut memunculkan banyak reaksi dari beberapa negara yang juga merasa berhak atas kawasan tersebut. Setidaknya ada enam negara yang berselisih di wilayah Laut China Selatan. Wilayah tersebut di antaranya adalah China, Vietnam, Taiwan, Filipina, Malaysia, dan Brunei. Setiap negara memiliki pandangannya masing-masing yang berbeda terkait kepemilikan atas kawasan tersebut. Klaim yang dilakukan oleh China, Taiwan, dan Vietnam didasarkan pada sejarah penemuan dan pendudukan pulau-pulau di gugusan Kepulauan Spratly dan Paracel, Filipina didasarkan pada kelanjutan klaim landas kontinen, sedangkan Malaysia dan Brunei mengklaim perpanjangan ZEE (Zona Ekonomi Eksklusif) dan landas kontinen Indonesia (Wiranto, 2016, hlm. 8). Konflik Laut China Selatan ini terus berlarut-larut dan tidak terselesaikan. Muncul kekhawatiran konflik ini akan meluas menjadi konflik keamanan regional dan menimbulkan potensi ancaman seperti yang diungkapkan oleh Riawan dan Kaya (1993, hlm. 42), bukan mustahil China (sebagai negara yang memiliki kekuatan militer paling potensial, jika dibandingkan dengan Vietnam sekarang) akan menggunakan segala sarana untuk menghadapi segala hal yang terjadi dalam menyelesaikan kasus di Spratly ini. Dan bila hal ini terjadi, akan ada ancaman dari China bagi negara-negara di kawasan Asia Tenggara.

ASEAN sebagai organisasi regional negara-negara Asia Tenggara merasa memiliki kewajiban untuk menjembatani negara-negara anggota ASEAN dengan China untuk menyelesaikan konflik Laut China Selatan ini. Dalam deklarasi ASEAN dinyatakan bahwa maksud dan tujuan ASEAN salah satunya adalah "Meningkatkan perdamaian dan stabilitas regional dan menjunjung tinggi keadilan dan tertib hukum dalam hubungan antar negara di kawasan Asia Tenggara dan berpegang pada asas Piagam PBB" (Kementerian Komunikasi dan Informasi Teknologi, 2014, hlm. 1). Sedikitnya empat negara ASEAN yang terlibat dalam sengketa ini yaitu Vietnam, Filipina, Malaysia dan Brunei. Tentunya ASEAN memiliki kewajiban untuk membela dan 
melindungi negara-negara anggotanya, apalagi perbedaan klaim dan pendapat China dan beberapa negaraASEANtersebut menjurus kepada penggunaan kekuatan militer, namun di sisi lain hubungan ekonomi antara ASEAN dan China sangat dekat dan strategis (Raharjo, 2014, hlm. 62). ASEAN menyadari posisinya sebagai organisasi regional yang berfungsi untuk menciptakan dan menjamin keamanan dan kestabilan di wilayah Asia Tenggara, yang juga membutuhkan China dalam kerjasama ekonominya, sehingga dalam upaya penyelesaian konflik Laut China Selatan, ASEAN mengambil jalan damai dengan menggunakan diplomasi melalui berbagai pendekatan. Laut China Selatan merupakan kawasan yang memiliki nilai sangat strategis, ekonomis dan politis. Konflik yang telah berlangsung cukup lama terus berlanjut tanpa menemui penyelesaian hingga saat ini.

Berangkat dari latar belakang tersebut, penulis mencoba mengangkat masalah utama: bagaimana pendekatan yang dilakukan oleh ASEAN dalam upaya penyelesaian konflik Laut China Selatan secara damai?. Penulis berharap tulisan ini dapat memberikan manfaat sebagai pelengkap tulisan sejarah yang berkaitan dengan organisasi regional dan global, khususnya materi pelajaran Sejarah (Peminatan) kelas XII Kurikulum 2013 dalam Kompetensi Dasar "3.2 Mengevaluasi Sejarah Organisasi Global dan Regional diantaranya: GNB, ASEAN, OKI, APEC, OPEC, MEE, GATT, WTO, NAFTA, dan CAFTA".

\section{METODE PENELITIAN}

Metode penelitian yang digunakan oleh penulis adalah metode historis atau metode sejarah. Menurut Abdurahman (2007, hlm. 53) metode sejarah dalam pengertiannya yang umum adalah penyelidikan atas suatu masalah dengan mengaplikasikan jalan pemecahannya dari perspektif historis. Lebih rinci dijelaskan oleh Ismaun (2005, hlm. 34) metode sejarah ialah rekonstruksi imajinatif tentang gambaran masa lampau peristiwaperistiwa sejarah secara kritis dan analitis berdasarkan bukti-bukti dan data peninggalan masa lampau yang disebut sumber sejarah. Dari kedua pengertian tersebut dapat disimpulkan bahwa metode sejarah ini mengkaji suatu masalah atau peristiwa yang dilihat dari sudut pandang sejarahnya, yaitu dengan cara menganalisis bukti-bukti yang ada dan berhubungan dengan masalah atau peristiwa tersebut, kemudian dilakukan rekonstruksi imajinatif. Menurut Gottschalk (2008, hlm. 23-24) prosedur penelitian dan penulisan sejarah bertumpu kepada empat pokok kegiatan, yaitu heuristik, kritik, interpretasi, dan historiografi.

Langkah pertama adalah heuristik, sebuah kegiatan mencari sumber-sumber untuk mendapatkan data-data, atau materi sejarah, atau evidensi sejarah (Sjamsuddin, 2012, hlm. 67). Pada tahap ini penulis melakukan pengumpulan sumber yang berguna untuk membantu menganalisis dan melakukan penyelesaian masalah. Pengumpulan sumber yang digunakan penulis ialah dengan mengumpulkan sumber tertulis yang dapat dipertanggungjawabkan diantaranya seperti buku, artikel dalam jurnal, artikel dalam surat kabar dan majalah serta data-data lainnya yang relevan. Sumbersumber tersebut diperoleh oleh penulis dari berbagai tempat seperti perpustakaan 
daerah, perpustakaan nasional, perpustakaan universitas, lembagalembaga seperti CSIS, dan internet.

Setelah melakukan kegiatan pengumpulan sumber, tahap selanjutnya adalah melaksanakan kritik sumber. Tujuan dari kritik adalah untuk menyaring sumber-sumber yang telah didapatkan, agar didapat sumber yang terpercaya, dan relevan dengan tema penelitian ini. Tahapan kritik terbagi menjadi dua yaitu, kritik internal dan kritik eksternal. Dalam melakukan kritik eksternal terhadap sumber-sumber tertulis berupa bukubuku, penulis tidak melakukan proses kritik sumber terlalu ketat dengan pertimbangan bahwa buku-buku tersebut merupakan sumber sekunder hasil cetakan yang didalamnya akan memuat nama penulis, tahun terbit, penerbit dan tempat buku tersebut diterbitkan. Dengan kriteria tersebut maka dapat dianggap sebagai salah satu bentuk pertanggungjawaban atas penggunaan buku yang telah diterbitkan. Kritik internal dilakukan dengan memperhatikan dua hal yaitu penilaian intrinsik terhadap sumber-sumber dan membanding-bandingkan kesaksian dari berbagai sumber agar sumber dapat dipercaya (diterima kredibilitasnya) (Priyadi, 2012, hlm. 67). Kritik internal yang dilakukan oleh penulis ialah dengan cara membaca keseluruhan isi sumber bacaan kemudian membandingkannya dengan sumber lainnya.

Langkah selanjutnya adalah interpretasi yang sering disebut dengan analisis sejarah. Analisis sejarah bertujuan untuk melakukan sintesis atas sejumlah fakta yang diperoleh dari sumber-sumber sejarah dan bersama-sama dengan teori menyusun fakta tersebut menjadi suatu interpretasi yang menyeluruh (Kuntowijoyo,1995,hlm.100).Dalamtahap ini penulis berusaha untuk merekonstruksi kembali peristiwa yang terjadi mengenai konflik Laut China Selatan. Rekonstruksi tersebut didasarkan pada fakta-fakta yang telah didapat. Adapun rekonstruksi tersebut dijadikan bahan untuk menjawab pertanyaan permasalahan yang telah ditentukan sebelumnya.

Langkah terakhir dalam metode penelitian sejarah adalah historiografi. Historiografi berupa pelukisan sejarah, gambaran tentang peristiwa masa lalu. Hal tersebut dilakukan dengan usaha mensintesiskan data-data dan faktafakta sejarah menjadi suatu kisah yang jelas dalam bentuk lisan maupun tulisan baik dalam buku atau artikel maupun perkuliahan sejarah (Ismaun, 2005, hlm. 28-29). Laporan hasil penelitian ini dituangkan ke dalam sebuah karya tulisan berupa artikel jurnal. Laporan tersebut disusun secara ilmiah berdasarkan dengan metode yang telah dirumuskan dan teknik penulisan yang sesuai dengan pedoman karya ilmiah.

\section{HASIL PENELITIAN DAN PEMBAHASAN}

Konflik Laut China Selatan sebelumnya merupakan konflik yang berlangsung secara bilateral antara China dengan masing-masing negara ASEAN yang merupakan claimant states (Vietnam, Filipina, Malaysia, dan Brunei) tanpa melibatkan ASEAN sebagai Organisasi Regional. Namun dalam perjalanannya, terutama setelah China membuat UndangUndang yang berhubungan dengan 


\section{R. WILDAN PRATAMA INDRA KUSUMAH, NANA SUPRIATNA, YANI KUSMARNI JALAN DAMAI MENUJU KEAMANAN REGIONAL: PENDEKATAN ASEAN DALAM UPAYA PENYELESAIAN KONFLIK LAUT CHINA SELATAN}

klaimnya terhadap Laut China Selatan, ASEAN berinisiatif mengadakan Manila Declaration on the South China Sea (Baviera, 2005, hlm. 345). Hal tersebut dilakukan karena permasalahan mengenai Laut China Selatan sudah sangat penting untuk segera dilakukan penyelesaiannya, karena telah melibatkan banyak negara dan dianggap mampu menganggu stabilitas keamanan kawasan. Dalam kesempatan tersebut ASEAN berharap agar dalam upaya-upaya penyelesaiannya dilakukan dengan cara yang damai.

Menurut Muhamad (2013, hlm. 123) terdapat beberapa pandangan yang berbeda mengenai jalan penyelesaian sengketa menurut masing-masing claimant states, China menghendaki agar masalah Laut Laut China Selatan tidak diinternasionalkan oleh negaranegara terkait. China dalam hal ini lebih menginginkan penyelesaian masalah Laut China Selatan dilakukan melalui perundingan bilateral dengan masingmasing negara pengklaim. Terkait dengan keterlibatan ASEAN, China berpendirian bahwa sengketa Laut China Selatan bukan isu antara ASEAN dengan China, tetapi antara China dengan negara anggota ASEAN terkait. Perjanjian dengan ASEAN adalah dalam rangka mutual partnership yang saling menguntungkan dan bukan dalam kerangka penyelesaian sengketa Laut China Selatan. Sementara itu, Filipina dan Vietnam lebih menginginkan penyelesaian sengketa melalui forum multilateral sesuai dengan ketentuan hukum intenasional yang berlaku.

Terlepas dari pandangan yang berbeda dari negara-negara pengklaim, ASEAN sebagai organisasi regional yang berpengaruh di kawasan dan beberapa anggotanya terlibat dalam sengketa Laut China Selatan, perlu mengambil peran dan mencari solusi atas permasalahan tersebut. Hal tersebut sejalan dengan salah satu tujuan pembentukan ASEAN yaitu "to promote regional peace and stability through abiding respect for justice and the rule of the law in the relationship among countries of the region and adherence to the principles of the United Nations Charter" (Putra \& Aqimuddin, 2011, hlm. 35) yang termasuk di dalamnya berperan dalam konflik Laut China Selatan agar stabilitas keamanan kawasan tetap terjaga. Menurut Caballero-Anthony (1998, hlm. 1) ASEAN selama kurang lebih 40 tahun sejak terbentuk sebagai organisasi internasional regional memiliki kemampuan untuk memelihara keamanan dan perdamaian di kawasan dan hal itu masih berlanjut hingga kini meskipun potensi sengketa di Asia Tenggara sangat rentan dan dapat memicu ketegangan. Dalam usahanya untuk menyelesaikan sengketa, ASEAN memiliki mekanismenya tersendiri yaitu mekanisme formal dan informal atau normatif. Mekanisme formal dapat dilakukan melalui tiga cara yaitu kerangka organisasi melalui diskusi dan konsultasi untuk mencari kepentingan bersama, mekanisme bilateral antar anggota dan instrument hukum (Caballero-Anthony, 2007, hlm. 55). Contoh dari mekanisme penyelesaian sengketa secara formal adalah dengan menggunakan Treaty of Amity and Cooperation in Southeast Asia (TAC). Namun dalam praktiknya, ASEAN sangat jarang menggunakan mekanisme formal-institusional dalam menyelesaikan sengketa. Mekanisme informal lebih sering diterapkan dengan menggunakan ASEAN Way (Putra \& Aqimuddin, 2011, hlm. 36). 


\section{ASEAN Way}

ASEAN Way dianggap sebagai mekanisme penyelesaian sengketa yang paling efektif dan bersifat informal. Davidson (2004, hlm. 167) mendefinisikan ASEAN Way ini sebagai proses yang melibatkan diskusi informal yang intensif dan hati-hati untuk mencari konsensus dengan cara pengambilan keputusan melalui mufakat lalu keputusan tersebut diadopsi dalam pertemuan yang bersifat formal. Secara singkat dapat diartikan bahwa terdapat dua komponen dalam mekanisme berdasarkan ASEAN Way ini yaitu musyawarah dan mufakat. Sebenarnya, konsep ASEAN Way sendiri merupakan konsep yang tidak pernah dikonsepkan secara eksplisit dan tidak ada dokumen resmi ASEAN yang menjelaskan tentang definisi tersebut (Hafez, 2004, hlm. 119). Namun konsep ini telah diketahui dan dipahami bahkan tersebar luas di antara negara-negara anggota ASEAN sehingga dapat diterima sebagai suatu konsep yang informal, sehingga dalam kasus penyelesaian sengketa, konsep ASEAN Way ini dijadikan sebagai landasan atau pedoman untuk menyelesaikan masalah tersebut secara damai.

Terkait dengan fungsinya sebagai mekanisme penyelesaian sengketa di ASEAN yang bersifat informal terdapat beberapa perbedaan pandangan mengenai status dan efektifitas dari mekanisme ini. Seperti yang dijelaskan oleh Weatherbee (2010, hlm. 128) ASEAN Way dengan musyawarah dan mufakatnya bukan dianggap sebagai suatu mekanisme dalam menyelesaikan sengketa, namun lebih sebagai suatu usaha untuk menghindari konflik dengan cara negosiasi. Lebih lanjut dijelaskan oleh Putra \& Aqimuddin (2011, hlm. 37) meskipun ASEAN Way tersebut dianggap berhasil menjaga stabilitas kawasan, konsep tersebut dapat melemahkan ASEAN sebagai suatu organisasi secara bertahap. Perbedaan motif pendirian yang awalnya dilakukan untukfokus terhadapkeamanan tradisional yang kemudian berubah menjadi fokus penguatan kerjasama di bidang keamanan non-tradisional (ekonomi, sosial budaya dan lain-lain), serta pihak yang terlibat dalam ASEAN yang semakin heterogen (bukan hanya sebatas negara-negara anggota saja, melainkan negara nonASEAN, organisasi internasional lainnya), maka ASEAN membutuhkan penguatan secara kelembagaan dengan menguatkan aturan main dalam organisasi. Misalnya dengan mekanisme penyelesaian sengketa yang sifatnya formal-institusional sehingga hukum menjadi pedoman utama dalam proses dan penyelesaian sengketa yang melibatkan ASEAN sebagai sebuah organisasi (rules-based organization).

\section{Treaty of Amity and Cooperation (TAC)}

Berbeda dengan ASEAN Way yang bersifat informal, Treaty of Amity and Cooperation atau yang lebih dikenal dengan singkatannya TAC justru bersifat lebih formal, sehingga dapat megikat secara resmi pihak-pihak yang terlibat dalam suatu persengketaan. Dapat dikatakan bahwa TAC ini merupakan perwujudan dari pedoman-pedoman yang terdapat dalam ASEAN Way yang memiliki kemampuan lebih mengikat secara hukum dengan ketentuan-ketentuan yang telah ditentukan. TAC merupakan hasil dari kesepakatan pada KTT pertama ASEAN di 
Bali yang ditandatangani pada tanggal 24 Februari 1976 (Severino, 2002, hlm. 25) sebagai jawaban atas perlunya prinsipprinsip dasar yang mengatur hubungan sesama anggota dan prosedur dalam penyelesaian sengketa melalui mekanisme formal-institusional. Adapun prinsipprinsip dasar yang terdapat dalam TAC (Solidum, 2003, hlm. 229) adalah sebagai berikut:

1. Mutual respect for the independence, sovereignty, equality, territorial integrity, and national identity of all nations;

2. The right of every state to lead its national exsistence free from external interference, subversion, or coercion;

3. Noninterference in the internal affairs of one another;

4. Settlement of differences or disputes by peaceful means;

5. Renunciation of the threat or use of force;

6. Effective cooperation among themselves.

Dari beberapa prinsip dasar tersebut jelas sekali mengisyaratkan bahwa dalam setiap penyelesaian sengketa yang dilakukan perlu mengedepankan keamanan bagi masing-masing pihak yang terlibat dalam persengketaan tersebut. Adapun metode penyelesaian sengketa dalam TAC (Putra \& Aqimuddin, 2011, hlm. 47-54) terbagi menjadi beberapa tahap. Tahap pertama adalah pencegahan, setiap negara peserta harus memiliki niat dan keiginan untuk mencegah serta mampu untuk menahan diri, sehingga tidak mengganggu stabilitas regional. Tidak dijelaskan secara rinci bagaimana proses yang perlu dilakukan untuk pencegahan tersebut, namun dapat ditafsirkan agar peserta menghormati prinsip-prinsip dasar mekanisme TAC.

Tahap kedua yaitu negosiasi, jika sengketa tetap timbul dan tidak bisa dicegah maka para pihak yang terlibat wajib menahan diri dengan tidak menggunakan ancaman atau kekuatan bersenjata. Sengketa diselesaikan dengan cara negosiasi secara baik-baik dan langsung, atau dengan menggunakan jasa-jasa baik, mediasi, penyelidikan, atau konsiliasi. Tahap ketiga melalui Dewan Tinggi (High Council), Dewan Tinggi mempunyai wewenang untuk menyelesaikan sengketa yang dapat mengganggu perdamaian dan keharmonisan regional. Dewan Tinggi terdiri dari perwakilan setiap negara peserta TAC yang dipilih oleh para negara peserta. Dewan Tinggi dapat dibentuk berdasarkan dua kemungkinan yaitu karena kegagalan menyelesaiakan sengketa melalui forum negosiasi atau atas dasar persetujuan para pihak untuk menyelesaikan sengketa mereka.

Peserta terdiri dari negara anggota ASEAN dan negara non Asia Tenggara yang telah disetujui. Pembentukan Dewan Tinggi ini hanya bisa dilaksanakan apabila telah disetujui oleh pihak yang bersengketa, sehingga tidak semua pihak dapat mengajukan pembentukan Dewan Tinggi kecuali disetujui pihak yang bersengketa meskipun kondisi perdamaian dan keharmonisan regional terganggu dan cukup membahayakan. Namun meskipun tidak terbentuk Dewan Tinggi, para peserta TAC dapat memberikan bantuan atau usulan untuk membatu proses penyelesaian sengketa. Jika didapatkan persetujuan dari negara yang bersengketa maka pembentukan 
Dewan Tinggi dapat segera dilakukan. Anggota Dewan Tinggi terdiri dari sepuluh orang perwakilan masing-masing negara ASEAN dan perwakilan dari negara non-ASEAN yang telah disetujui dan terlibat dalam sengketa. Dewan Tinggi tersebut dipimpin oleh seorang ketua yang merupakan standing committee ASEAN (otomatis) atau dipilih sendiri oleh anggota Dewan Tinggi (alternatif) dan tidak terlibat dengan sengketa yang berlangsung. Putusan dilakukan berdasarkan konsensus meskipun sifatnya tidak terlalu jelas apakah mengikat atau tidak. Putusan berupa rekomendasi atau tindakan lain. Sanksi dalam putusan juga tidak diatur secara tegas.

Konflik Laut China Selatan termasuk ke dalam sengketa yang jelas dapat mengganggu perdamaian dan keharmonisan regional Asia Tenggara. Hal menarik terjadi di tahun 2003, setelah sekian lama menunggu China untuk mengakui keberadaan TAC sebagai salah satu perjanjian dalam kerjasama dalam hal perdamaian dan keamanan di kawasan, akhirnya China bersedia untuk menandatagani dokumen TAC tersebut (Yong, 2005, hlm. 21). Dengan demikian, berarti China memastikan akan mengikuti prinsip-prinsip dasar TAC yang secara garis besar menghargai perdamaian dan keharmonisan kawasan tanpa menggunakan kekuatan militer yang dapat mengganggu stabilitas keamanan. Selain itu, hal ini menandakan hubungan kerjasama yang lebih lanjut antara China dengan para peserta TAC secara umum, dan dengan ASEAN secara khusus. Kerjasama yang dibentuk ini lebih banyak berfokus dalam menjaga keamanan dan kenyamanan di kawasan, namun tidak menutup kemungkinan dapat diselenggarakan kerjasama dalam berbagai bidang-bidang lainnya.

\section{ASEAN Regional Forum (ARF)}

ASEAN Regional Forum atau yang lebih sering disebut dengan sigkatannya ARF dapat dikatakan sebagai penggabungan dari dua mekanisme yang telah dijelaskan sebelumnya. Menurut Severino (2009, hlm. 41) ARF endorse the purposes and principles of ASEAN's Treaty of Amity and Cooperation in Southeast Asia, as a code of conduct governing relation between stases and a unique diplomatic instrument for regional. Selain itu, ASEAN Way juga diadopsi menjadi pedoman untuk ARF Way, yaitu cara-cara yang dilakukan oleh ARF dalam upayanya untuk penyelesaian sengketa. ARF dikatakan sebagai perwujudan institusional framework dari ASEAN Way.

Dalam perkembangannya dalam usaha penyelesain konflik Laut China Selatan, ARF berusaha terus mengajak China untuk bergabung menjadi bagiannya. China diaggap merupakan kunci dari penyelesaian sengketa tersebut. Dalam ARF dilakukan diskusi mengenai masalah keamanan di kawasan Asia Pasifik secara umum dan Asia Tenggara secara khusus. Tapi dalam pertemuan ARF yang pertama masalah sengketa dianggap masih terlalu sensitif untuk dijadikan topik pembicaraan (Usman \& Sukma, 1997, hlm. 76). ASEAN tidak menginginkan awal pembentukan ARF diwarnai dengan topik yang dapat menimbulkan ketidaksenangan pihak China. Diharapkan melalui ARF China dapat berkontribusi untuk membangun rasa saling percaya sehingga masalah- 


\section{R. WILDAN PRATAMA INDRA KUSUMAH, NANA SUPRIATNA, YANI KUSMARNI JALAN DAMAI MENUJU KEAMANAN REGIONAL: PENDEKATAN ASEAN DALAM UPAYA PENYELESAIAN KONFLIK LAUT CHINA SELATAN}

masalah keamanan dapat diselesaikan secara bersama-sama.

Menurut Haacke (2003, hlm. 116) ada beberapa alasan mengapa China tidak mau terlibat dengan dialog multilateral tersebut. Namun, atas dasar beberapa pertimbangan akhirnya China kemudian bergabung dengan ARF. Ketakutan China untuk bergabung dalam ARF rupanya didasarkan pada kehadiran Jepang dan Amerika Serikat yang dapat dikatakan sebagai musuh bebuyutan China. China memiliki ketakutan bahwa reputasinya yang merupakan kekuatan besar yang terus berkembang khususnya di kawasan Asia Pasifik akan direbut oleh Jepang yang memang memiliki kekuatan yang besar pula. Selain itu, China yang sejak awal lebih memilih untuk menyelesaikan permasalahan internasionalnya secara bilateral, menghawatirkan dengan bergabungnya China dalam ARF setiap permasalahan yang khususnya berkaitan dengan sengketa akan menjadi bahan konsumsi internasional. Kehadiran Amerika Serikat yang dikenal cukup memiliki kedekatan dengan negaranegara Asia Tenggara dikhawatirkan akan memanipulasi forum tersebut dan menjadikannya sebagai ajang untuk meruntuhkan kekuasaan China. Namun dibalik beberpa ketakutan tersebut, China kemudian memutuskan bergabung karena memang forum tersebut juga memberikan dampak-dampak positif bagi keberadaan China sebagai sebuah negara diantaranya untuk mencegah dari bahaya yang mungkin menyerang kepentingan nasional, sebagai negara yang memiliki kekuatan yang besar perlu untuk berkontribusi, dan tentunya beberapa agenda yang salah satunya adalah meningkatkan hubungan dengan
ASEAN dalam segala aspek. Agenda terakhir yang ingin dicapai China tersebut menandai keinginan besar China untuk menjalin hubungan kerjasama yang lebih baik dengan ASEAN.

ARF dianggap sebagai track-one diplomacy yang berarti diskusi atau diplomasi jalur pertama yang bersifat formal. Di kawasan Asia Pasifik sendiri track-one diplomacy biasanya dilengkapi dengantrack-twodiplomacyyaitudiplomasi jalur kedua yang bersifat informal. Pendekatan ini memudahkan saling tukar pendapat dan ide yang tidak terikat pada sikap-sikap resmi pengungkapnya, yang kemudian melahirkan pusat atau lembaga studi strategi dan internasional (Luhulima, 2007, hlm. 76). Salah satu contoh dari track-two diplomacy adalah Councils for Security Cooperation in the Asia Pasific (CSCAP) yang berdiri sejak 1993. CSCAP menyediakan wadah diskusi antara regional security-oriented dengan individual dalam topik yang menjadi agenda di ARF. Track-two diplomacy ini mampu membicarakan isu yang sensitif yang biasanya dihindari oleh pemerintah karena adanya tekanan-tekanan dalam politik dan diplomasi (Weatherbee, 2010, hlm. 162).

ARF biasanya diselenggarakan bersamaan dengan ASEAN Minestrial Meeting (AMM). Dalam setiap pertemuannya selalu dibahas mengenai isu-isu yang berkaitan dengan keamanan regional. Dalam pertemuannyayang kedua, ARF membentuk tiga tahapan proses yang mampu mendukung keamanan dan kerjasama kawasan. ARF mempromosikan confidence-building, development of preventive diplomacy, and elaboration of approaches to conflict sebagai three- 
phases process of security dialogue and cooperation (Xuecheng, 2005, hlm. 40). Tahapan-tahapan tersebut diterapkan untuk mencegah konflik Laut China menjadi konflik terbuka yang mengganggu perdamaian di kawasan. Dengan confidence-building diharapkan pihakyang terkait dapat mengurangi ketegangan yang terjadi dan dapat mencari penyelesaian sengketa yang dapat membuka jalan untuk perjanjian yang lebih komprehensif. Dengan preventive diplomacy diharapkan dapat mencegah tidakan-tindakan kolektif yang mengganggu perdamaian dan dapat digunakan untuk mencegah konflik sejak dini baik dengan aksi diplomasi, politis, ekonomi, maupun kemanusiaan. Sementara tindakan elaboration of approach to conflict atau yang dapat juga disebut dengan conflict resolution merupakan upaya lebih jauh yang dilakukan setelah kedua tahapan tersebut telah dilaksanakan. Dalam conflict resolution ini juga dapat memuat mengenai penyelesaian konflik atau upaya kerjasama setelah konflik (Wiranto, 2016, hlm. 174).

Kebudayaan yang tercipta dalam masyarakat tidak terlepas dari adanya interaksi atau aktifitas sesama anggota masyarakatnya. sejarah muncul dan perkembangan Angklung Gubrag.

\section{SIMPULAN}

Berdasarkan penelitian, hasil yang didapatkan diantaranya adalah sebagai berikut. PertaSma, konflik Laut China Selatan terjadi di antara China dengan negara-negara anggota ASEAN seperti Vietnam, Filipina, Malaysia dan Brunei. Negara-negara tersebut dikenal dengan istilah claimant states. Konflik yang terjadi diakibatkan oleh perebutan klaim atas wilayah kepulauan, perairan, serta fitur-fitur lain dari Laut China Selatan khususnya Kepulauan Paracel dan Kepulauan Spratly. Klaim tersebut didasarkan kepada kepentingan masingmasing negara terhadap potensi-potensi yang dimiliki oleh Laut China Selatan. Potensi tersebut mencakup ketersediaan minyak bumi serta gas alam yang melimpah didukung dengan kandungan-kandungan mineral yang terdapat di dalamnya, potensi perikanan yang dapat memenuhi kebutuhan konsumsi bagi negara-negara di sekitarnya, potensi yang terakhir adalah Laut China Selatan sebagai jalur pelayaran yang penting. Jalur tersebut dijadikan rute perdagangan negara-negara di kawasan Asia Tenggara bahkan negara-negara besar lainnya.

Kedua, klaim yang dilakukan juga didasarkan kepada faktor historis, kedekatan wilayah serta aturan hukum laut. Laut China Selatan termasuk laut semi tertutup (semi-enclosed sea) yang mengakibatkan letaknya terkurung oleh negara-negara lain. Sehingga sulit untuk menentukan batas maritim bagi kepemilikan laut tersebut. Kawasan Asia Tenggara yang bersifat heterogen menjadi tantangan tersendiri bagi penyelesaian konflik ini.

Ketiga, perbedaan pandangan di antara China dan negara-negara anggota ASEAN terkait upaya penyelesaian sengketa di Laut China Selatan mengakibatkan sulitnya konflik tersebut untuk diselesaikan. China menganggap koflik yang terjadi tersebut bukan urusan ASEAN sehingga dalam penyelesaiannya pun ASEAN tidak berhak ikut campur. China menegaskan 


\section{R. WILDAN PRATAMA INDRA KUSUMAH, NANA SUPRIATNA, YANI KUSMARNI JALAN DAMAI MENUJU KEAMANAN REGIONAL: PENDEKATAN ASEAN DALAM UPAYA PENYELESAIAN KONFLIK LAUT CHINA SELATAN}

bahwa hubungannya dengan ASEAN hanya sebatas hubungan kerjasama dalam hal ekonomi dan bidang-bidang lainnya yang menguntungkan. China juga memastikan bahwa konflik Laut China Selatan tidak akan berpengaruh terhadap hubungan kerjasama tersebut. China akan menyelesaikan sengketanya dengan masing-masing negara melalui hubungan bilateral dengan negara-negara terkait. Di sisi lain, negara-negara anggota ASEAN yang tergolong ke dalam claimant states berharap ASEAN sebagai organisasi regional yang menaungi negara-negara di kawasan Asia Tenggara dapat menjadi jembatan untuk penyelesaian konflik yang terjadi karena hal tersebut sejalan dengan tujuan ASEAN untuk menjaga perdamaian dan stabilitas keamanan kawasan.

Keempat, ASEAN telah melakukan berbagai macam upaya untuk menyelesaikan sengketatersebut darimulai penggunaan mekanisme informal seperti ASEAN Way, mekanisme formal melalui Treaty of Amity and Cooperation dan mekanisme semi-formal melalui ASEAN Regional Forum. Mekanisme-mekanisme tersebut memiliki kelemahan dan keunggulannya masing-masing. Meskipun mekanisme-mekanisme tersebut belum mampu untuk menyelesaikan konflik Laut China Setatan secara menyeluruh, namun setidaknya terjadi perkembangan yang mengarah kepada jalan damai sebagai penyelesaian konflik. ASEAN Way telah mampu meyakinkan negara-negara intraASEAN untuk meyelesaikan konflik melalui jalan damai, konsep tersebut dijadikan pedoman untuk tidak menggunakan paksaan melalui senjata dan militer melainkan menggunakan diplomasi dan negosiasi dalam meredam konflik. TAC telah mampu membuka jalan bagi China untuk ikut serta dalam menyuarakan kerjasama dalam perdamaian dan membuka diri dengan ASEAN. ARF telah membuka pandangan ASEAN akan pentingnya kerjasama multilateral, China bersedia untuk melakukan diskusi melalui forum ini. Dengan tiga tahapan yaitu confidence building, preventive diplomacy, dan conflict resolution diharapkan forum ini bukan hanya mampu untuk menyelesaiakan permasalahan tapi juga diarahkan untuk melakukan kerjasama.

Kelima, konflik Laut China Selatan memang cukup sulit untuk diselesaikan, perlu adanya kesepahaman antara negara-negara claimant states dalam memahami permasalahan mengenai konflik ini. Kontribusi dari negaranegara non-claimant states pun perlu terus dilakukan untuk medukung penyelesaian. Negara-negara besar perlu memposisikan dirinya secara proposional dalam keikutsertaannya di Laut China Selatan jangan sampai kehadirannya justru dianggap mengintimidasi dan malah melahirkan konflik baru yang tidak perlu. Konflik Laut China Selatan menjadi tantangan tersendiri bagi ASEAN sekaligus menjadi pembuktian diri apakah organisasi regional masih relevan dan mampu menjadi jembatan untuk menjaga perdamaian dan keamanan kawasan. Sampai tahap ini konfik Laut China Selatan memiliki dua potensi penyelesaian apakah dapat diselesaikan dengan damai atau justru membuka jalannya konflik militer. Jika melihat berbagai perkembangan melalui mekanisme yang dilakukan ASEAN kemungkinan besar konflik ini dapat diselesaikan dengan damai. Jalan menuju pembentukan Code Of Conduct 
(COC) telah terbuka lebar. Meskipun dalam penyusunannya perlu melalui proses yang cukup panjang. Selain itu, konflik ini mampu melahirkan kerjasamakerjasama dalam pengelolaan wilayah Laut China Selatan.

Alat musik Angklung Gubrag sudah digunakan sejak lama oleh masyarakat Cigudeg sebagai media ritual dalam upacara Seren Taun yang bertujuan untuk memuja Nyi Pohaci. Penggunaannya dalam upacara ritual dipengaruhi oleh pola pikir dan ke

\section{DAFTAR PUSTAKA}

Abdurahman, D. (2007). Metodologi Penelitian Sejarah. Yogyakarta: ArRuzz Media.

Abdurahman, D. (2007). Pengantar Metode Penelitian. Yogyakarta: Kurnia Alam Semesta.

Akmal., \& Pazli. (2016). Strategi Indonesia Menjaga Keamanan Wilayah Perbatasan terkait Konflik Laut Cina Selatan pada Tahun 2009-2014. Journal of International Society, 3(1), 1-13.

Baviera,A.S.P.(2005). TheSouth ChinaSea Disputes After the 2002 Declaration: Beyond Confident-Building. Dalam Hock, S. S., Lijun, S., Wah, C. K. (Eds.), ASEAN-China Relations: Realities and Prospects (hlm. 344-355). Singapore: ISEAS Publications.

Caballero-Anthony, M. (1998). Mechanism of Dispute Settlement: The ASEAN Experience. Contemporary Southeast Asia, 20(1), hlm. 1.

Caballero-Anthony, M. (2007). Regional Security in Southeast Asia: Beyond the ASEAN Way. Singapura: ISEAS.
Cunningham, F. (2002). Theories of Democracy: A Critical Introduction. New York: Routledge.

Daliman, A. (2012). Metode Penelitian Sejarah. Yogyakarta: Ombak.

Davidson, P.J. (2004). The Role of Law in ASEAN Economic Cooperation. Singapura: Yearbook of International Law.

Finberg, H.P.R. dan Skipp, V.H.T Skipp. (1973). Local history: objective and pursuit. Newtown Abbott: David \& Charles

Gottschalk, L. (2008). Mengerti Sejarah. Jakarta: UI Press.

Haacke, J. (2003). Aseans Diplomatic and Security Culture: Origins, Development and Prospects. USA: Routledge.

Hafez,Z.(2004).TheDimensionofRegional Trade Integration in Southeast Asia. New York: Transnational Publisher.

Ismaun. (1992). Pengantar Ilmu Sejarah. Bandung: Jurusan Pendidikan Sejarah FPIPS IKIP Bandung.

Ismaun. (2005). Pengantar Belajar Sejarah sebagai Ilmu dan Wahana Pendidikan. Bandung: Tim Kreatif Jurusan.

Kasenda, P. (2013). Soeharto: Bagaimana Ia Bisa Melanggengkan Kekuasaan Selama 32 Tahun?. Jakarta: PT. Kompas Media Nusantara.

Kementerian Komunikasi dan Informasi Teknologi. (2014). ASEAN: Komunitas ASEAN 2015. Jakarta: Kominfo.

Kuntowijoyo. (1995). Pengantar Ilmu Sejarah. Yogyakarta: Bentang Budaya. Kuntowijoyo. 2001. Pengantar Ilmu Sejarah. Yogyakarta: Bentang Budaya. Kuntowijoyo. 2008. Penjelasan Sejarah (Historical Explanation). Yogyakarta: Tiara Wacana. 
R. WILDAN PRATAMA INDRA KUSUMAH, NANA SUPRIATNA, YANI KUSMARNI JALAN DAMAI MENUJU KEAMANAN REGIONAL: PENDEKATAN ASEAN DALAM UPAYA PENYELESAIAN KONFLIK LAUT CHINA SELATAN

Langlois, CH.V., \& Seignobos. CH. (2015) Introduction to the Study of History. Terjemahan Supriyanto Abdullah. Yogyakarta: Indoliterasi.

Luhulima, C. P. F. (2007). Pendekatan Multi-track dalam Penyelesaian Sengketa Laut Cina Selatan: Upaya dan Tantangan. Global Jurnal Politik Internasional, 9(1), hlm. 75-85.

Matsui, Y. (2002). Perempuan Asia dari Penderitaan Jadi Kekuatan. Jakarta: Yayasan Pustaka Obor Indonesia.

Muhamad, S. V. (2013). Sengketa Laut China Selatan dan Solusi Damai ASEAN. Dalam Nainggolan, P. P, Konflik Laut China Selatan dan Implikasinya Terhadap Kawasan (hlm. 105-140). Jakarta: Pusat Pengkajian, Pengolahan Data dan Informasi (P3DI) dan Azza Grafika.

Nainggolan, P. P. (Ed.). (2013). Konflik Laut China Selatan dan Implikasinya terhadap Kawasan. Jakarta: Pusat Pengkajian, Pengolahan Data dan Informasi (P3DI) dan Azza Grafika.

Poesponegoro, M. D., \& Notosusanto, N. (2008). Sejarah Nasional Indonesia IV: Zaman Jepang dan Zaman Republik Indonesia (+- 1942-1998). Jakarta: Balai Pustaka.

Pranoto,S.W.(2010).TeoridanMetodologi Sejarah. Yogyakarta: Graha Ilmu

Priyadi, S. (2012). Metode Penelitian Pendidikan Sejarah. Yogyakarta: Ombak.

Putra, H. T., \& Aqimuddin, E. A. (2011). Mekanisme Penyelesaian Sengketa di ASEAN: Lembaga dan Proses. Yogyakarta: Graha Ilmu.

Raharjo, S. N. I. (2014). Peran Indonesia dalam Penyelesaian Sengketa Laut Tiongkok Selatan. Jurnal Penelitian Politik, 11, hlm. 55-70.
Renier, G.J. (1961). History, its puspose and method. London: George Allen Unwin Ltd.

Riawan, F., \& Kaya, R. (1993, 7 September). "Spartly dalam Perspektif Keamanan Asia Tenggara". Teknologi Strategi Militer, hlm. 40-42.

Ricklefs, M.C. (1991). Sejarah Indonesia Modern. Yogyakarta: Gajah Mada University Press.

Sanit, A. (2011). Sistem Politik Indonesia: Kestabilan, Peta Kekuatan Politik, dan Pembangunan. Jakarta: Grafindo Persada.

Severino, R. (2002). ASEAN Today and Tomorrow. Jakarta: ASEAN Secretariat.

Severino, R. C. (2009). The ASEAN Regional Forum. Singapore: ISEAS.

Sjamsuddin, H. (1996). Metodologi Sejarah. Jakarta: Depdikbud Proyek Pendidikan Tenaga Akademik.

Sjamsuddin, H. (2012). Metodologi Sejarah. Yogyakarta: Ombak.

Solidum, E. D. (2003). The Politics of ASEAN: An Introduction to Southeast Asian Regionalism. Singapore: Eastern Universities Press.

Usman, A., \& Sukma, R. (1997). Konflik Laut Cina Selatan: Tantangan bagi ASEAN. Jakarta: Centre for Strategic and International Studies.

Weatherbee, D. E. (2010). International Relations in Southeast Asia: The Struglge for Autonomy. Singapore: Rowman \& Littlefield Publishers.

Wiharyanto, A. K. (2011). Sejarah Indonesia: Dari Proklamasi sampai Pemilu 2009. Yogyakarta: Universitas Sanata Dharma.

Wiranto, S. (2016). Resolusi Konflik Menghadapi Sengketa Laut Tiongkok Selatan dari Perspektif 
Hukum Internasional. Yogyakarta: Yong, O. K. (2005). Securing a Win-Win Leutikaprio. Partnership for ASEAN and China. Xuecheng, L. (2005). Strengthening ASEAN-China Cooperation in the Dalam Hock, S. S., Lijun, S., Wah, C. ASEAN Regional Forum. Dalam Hock, S. S., Lijun, S., Wah, C. K (Eds.), ASEAN-China Relations: Realities and $K$ (Eds.), ASEAN-China Relations: Realities and Prospects (hlm. 19-26). Singapore: ISEAS Publications.

Prospects (hlm. 40-48). Singapore: ISEAS Publications. 